\title{
HV-TURBO Single-stage High-speed Centrifugal Blower Analysis on Reasons for High Oil Temperature Failure and Measures
}

\author{
Shanghai Municipal Investment Sewage Treatment Co., Ltd., Shanghai, 200942, China
}

\section{Introduction}

HV-TURBO single-stage highspeed centrifugal blower has a series of advantages, such as significant energy-saving, reliable operation, wide adaptability, easy maintenance, etc. However, factors, such as regional high temperature of the surrounding environment in the summer, improper configuration of oil cooler and improper maintenance, will pose serious threats or even cause damage to the safe and stable operation of the blower and production system it serves. ${ }^{1} 8$ KA22SVGL225 single-stage high-speed centrifugal blowers used by Shanghai Shidongkou Sewage Treatment Factory are taken as an example in the paper for clarification.

The maximum air volume, maximum exhaust pressure, spindle speed and matching power as per KA22SV-GL225 single-stage high-speed centrifugal blower of Shidongkou factory are 20,671 m3/h, 1.750 bar, 11,781 rpm and $500 \mathrm{kw}$ respectively. ${ }^{2}$ Since its installation in 2003, it has played an important role in the production process of the integrated biological reaction tank, which is the key equipment to ensure that sewage treatment of Shidongkou meets standards of production and operation. The design of the unit uses parallel operation of the pipe network, i.e. 3 working and 5 spare devices or 4 working and 4 spare devices, which shall be switched regularly every month. Over the years, 8 single-stage high-speed blowers have been alternately operating with high efficiency, and the overall operation is in good condition, which can basically meet the daily needs of the actual production process. However, we also clearly see that failure of 8 centrifugal blowers caused by "high oil temperature" every year is very frequent, which has resulted in great adverse effects and security risks in the production system to meet the standards and operation of the equipment. 3 Statistics of main common failures before the transformation of the oil cooling system in the centrifugal blower Shidongkou are shown in Table 1.

\begin{abstract}
The paper mainly carries out the technical analysis on the causes of high oil temperature failure prevalent in HV-TURBO single-stage high-speed centrifugal blowers to put forward practical and feasible measures and methods, and takes Shidongkou Sewage Treatment Factory to verify the implementation of project cases. Good achievements are obtained in production practice, which further clarifies the necessity of the analysis on the reasons of failures and measures, being great reference significance for the proper solution to problems of the same type of equipment under scheduled circumstances.
\end{abstract}

Key words: Single-stage high-speed centrifugal blower; High oil temperature failure; Oil cooling system; Dynamic; Thermal equilibrium

Published online: 30th Sept, 2017

\begin{tabular}{|c|c|c|c|c|c|c|}
\hline Year & $\mathbf{2 0 0 3}$ & $\mathbf{2 0 0 4}$ & $\mathbf{2 0 0 5}$ & $\mathbf{2 0 0 6}$ & $\mathbf{2 0 0 7}$ & $\mathbf{2 0 0 8}$ \\
\hline High oil & 302 & 417 & 140 & 84 & 49 & 10 \\
\hline Surge & 82 & 1 & 0 & 5 & 4 & 2 \\
\hline Circulation & 5 & 13 & 19 & 20 & 3 & 0 \\
\hline Low oil pressure & 2 & 0 & 1 & 0 & 0 & 0 \\
\hline Motor winding & 0 & 0 & 1 & 0 & 0 & 0 \\
\hline Others & 1 & 0 & 0 & 0 & 1 & 0 \\
\hline
\end{tabular}

Table 1. Statistics of main common failures before the transformation of the oil cooling system in the centrifugal blower Shidongkou 
Data show that high oil temperature failure accounts for more than $77 \%$ in various types of unplanned failures with the maximum of $96.75 \%$, which ranks first in various types of failure. Among them, "high oil temperature" failure has occurred generally from the beginning of each year in early March until the end of October for as long as 8 months, which has a great impact on the steady operation of the treatment and production of sewage. Especially in 2004, the accumulated of "high oil temperature" failure alone reached up to 417 times, and in terms of serious "high oil temperature" failure, failure of the unit in one day reached as much as 31 times. $^{4}$

It can be seen that in order to ensure the safe and smooth operation of the production and eliminate or reduce the passive situation caused to production and operation and management due to similar failure, it is necessary to make researches and analysis on the reasons for high oil temperature failure so as to put forward practical measures and methods, which has very positive practical significance.

\section{Analysis on Reasons for High Oil Temperature Failure}

As we all know, operation of the lubricating system of the centrifugal blower is mainly a dynamic process of thermal equilibrium, and in terms of absorbing and emitting heat of lubricating oil, relative stability or smaller range of fluctuation around the optimum operating point (t0 $=40{ }^{\circ} \mathrm{C}$ ) shall be ensured. According to the first law of thermodynamics $\mathrm{W}+\mathrm{Q}=\Delta \mathrm{E}$, we can see that the mechanical operation of the blower is a work process, which is also a kind of the heating process. The amount of heat generated depends on the amount of work, i.e. amount of load adjustment of the equipment. When the lubricating operating point is seriously below the optimum point, the temperature point can be increased by the automatic electric heater, especially before the start of early operation in winter or the prelubricating stage before the start; when the lubricating operating point is above the optimum point, necessary adjustment and cooling shall be conducted within a certain range through its oil cooling system. ${ }^{5}$ In terms of normal and stable operation, the processes of radiating and generating heat maintain basic dynamic stability and balance, that is, $\mathrm{Q}$ absorb $=\mathrm{Q}$ radiate. Once this thermal equilibrium is damaged or the performance of main cooling factors is seriously decreased, it is bound to increase the dependence on other main and secondary factors, resulting in the fact that the optimum equilibrium operating point will shift up, and when the new thermal equilibrium point cannot be timely and stably established, it will eventually lead to "high oil temperature" failure.

\subsection{Heat-Generating Factors}

Through on-site observation and monitoring, direct heat sources resulting in the temperature rise of the oil system for KA22SV-GL225 high-pressure centrifugal blower are:

1) Heat generated by meshing transmission and bearing bush friction of gear wheels of operating gearbox.

2) Heat of the coil winding brought out by the motor cool-ing exhaust.

3) Heat transmitted to the gearbox by the fan rotor, volute, oil seal and other components.

4) Heat generated by the start of the electric heater of the basic tank. ${ }^{6}$

\subsection{Cooling Factors}

For the centrifugal blower in general, the oil cooling system is mainly composed of the oil cooler, gearbox, shell of the fan, external surface of the tank, oil pipeline, lubricating oil, its external operating environment conditions and other compo-nents. ${ }^{7}$ Among them, the oil cooler and lubricating oil are main factors that determine the cooling equilibrium of the oil system, and external operating environment conditions are secondary factors.

In short, as for heat-generating and cooling factors that affect the thermal equilibrium of the oil cooling system of the centrifugal blower, and whether they are major factors or secondary factors, they shall be regarded as variable factors and shall be comprehensively monitored and system measures shall be improved, and regular cleaning and inspection and related maintenance shall be carried out. In terms of oil improper design and selection of cooling factors of the oil system or the fact that changes in regional environ-mental deviate a lot from primary selection, technical transformation shall be conduct-ed reasonably to improve the deficient system and ensure the stable operation of the equipment.

\section{Project Case}

Take the Shidongkou Factory as an example, since the installation and implementation of the centrifugal blower in 2003, there has been serious high oil temperature failure in summer, which fully indicates the unreasonable configuration of the cooler of the lubricating oil system and the phenomenon of serous environment with high temperature around regions. Simultaneously, oil cooler block-ed with ash, damaged oil cooler, etc. also reflect improper management during the use and maintenance, and all of these have affected the establishment and stabilization of the thermal equilibrium of the oil cooling system during its normal operation of centrifugal blowers in Shidongkou.

In view of the above reasons and combined with the relevant analysis and solutions that have been discussed, the technical transformation of the original oil cooling system of the centrifugal 
blower shall be reasonably conducted, and effective measures shall be actively taken. Through the research, we believe that there are three solutions to solve the problem of high oil temperature in the oil cooling system of the blower: Solution 1 : drainage/pressure air-cooled primary heat transfer (enhanced), that is, remain the existing air- cooled configuration, strengthen the convective heat transfer rate, and improve the flow state of gas and characteristics of exhaust pipes; Solution 2: DC water-cooled + air-cooled secondary heat transfer, that is, on the basis of Solution 1, add stainless steel water-cooled coil heat exchanger in the tank of the oil system; Solution 3: air-cooled + circulating water-cooled secondary heat transfer, that is, change the type of oil cooler and cooling media and use efficient water-cooled heat exchanger, and the circulating water cooling system shall also be equipped with.8 Comprehensive comparison of three solutions is shown in the Table 2.

\begin{tabular}{|c|c|c|c|c|c|c|c|c|c|c|c|}
\hline Solution & $\begin{array}{l}\text { Type of heat } \\
\text { transfer }\end{array}$ & $\begin{array}{l}\text { Degree } \\
\text { of heat } \\
\text { transfer }\end{array}$ & $\begin{array}{l}\text { Effect of } \\
\text { heat } \\
\text { transfer }\end{array}$ & Area & $\begin{array}{l}\text { Operat } \\
\text { ing } \\
\text { cost }\end{array}$ & $\begin{array}{l}\text { Difficult } \\
y \text { of the } \\
\text { project }\end{array}$ & $\begin{array}{l}\text { Construc } \\
\text { tion } \\
\text { period }\end{array}$ & $\begin{array}{l}\text { Security } \\
\text { risks }\end{array}$ & $\begin{array}{l}\text { Operat } \\
\text { ional } \\
\text { flexibil } \\
\text { ity }\end{array}$ & $\begin{array}{l}\text { Proje } \\
\text { ct } \\
\text { cost }\end{array}$ & $\begin{array}{l}\text { Compr } \\
\text { ehensi } \\
\text { ve } \\
\text { evaluat } \\
\text { ion } \\
\end{array}$ \\
\hline $\begin{array}{l}\text { Solution } \\
1\end{array}$ & Air-cooled & Primary & Obvious & N/A & $\begin{array}{l}\text { Relativ } \\
\text { ely } \\
\text { low }\end{array}$ & Simple & $\begin{array}{l}\text { Relativel } \\
\text { y short }\end{array}$ & N/A & $\begin{array}{l}\text { Relativ } \\
\text { ely } \\
\text { low }\end{array}$ & $\begin{array}{l}\text { Relat } \\
\text { ively } \\
\text { low }\end{array}$ & Good \\
\hline $\begin{array}{l}\text { Solution } \\
2\end{array}$ & $\begin{array}{l}\text { Water- } \\
\text { cooled + air- } \\
\text { cooled }\end{array}$ & $\begin{array}{l}\text { Seconda } \\
\text { ry }\end{array}$ & $\begin{array}{l}\text { Relativel } \\
\text { y good }\end{array}$ & N/A & N/A & $\begin{array}{l}\text { Commo } \\
\mathrm{n}\end{array}$ & $\begin{array}{l}\text { Relativel } \\
\text { y long }\end{array}$ & $\begin{array}{l}\text { Relativel } \\
\text { y high }\end{array}$ & $\begin{array}{l}\text { Relativ } \\
\text { ely } \\
\text { good }\end{array}$ & $\begin{array}{l}\text { Relat } \\
\text { ively } \\
\text { low }\end{array}$ & Good \\
\hline $\begin{array}{l}\text { Solution } \\
3\end{array}$ & $\begin{array}{l}\text { Air-cooled }+ \\
\text { water-cooled }\end{array}$ & $\begin{array}{l}\text { Seconda } \\
\text { ry }\end{array}$ & $\begin{array}{l}\text { Relativel } \\
\text { y good }\end{array}$ & $\begin{array}{l}\text { Relat } \\
\text { ively } \\
\text { large }\end{array}$ & $\begin{array}{l}\text { Relativ } \\
\text { ely } \\
\text { high }\end{array}$ & $\begin{array}{l}\text { Complic } \\
\text { ated }\end{array}$ & $\begin{array}{l}\text { Relativel } \\
\text { y long }\end{array}$ & $\begin{array}{l}\text { Relativel } \\
\text { y high }\end{array}$ & $\begin{array}{l}\text { Relativ } \\
\text { ely } \\
\text { good }\end{array}$ & $\begin{array}{l}\text { Relat } \\
\text { ively } \\
\text { high }\end{array}$ & $\begin{array}{l}\text { Relativ } \\
\text { ely } \\
\text { good }\end{array}$ \\
\hline
\end{tabular}

Table 2. Comprehensive comparison of three solutions 
As for the description of the above three solutions, we find that [Solution 1] and [Solution 3] are more in line with the target of transformation.

The diagram for the transformation of the oil cooling system using the primary aircooled (enhanced) + secondary water-cooled (circulating) is shown in Figure 1.

The original air-cooled heat exchanger is retained and strengthened with the new circulating water-cooled heat exchanger used in the series. Simultaneously, add the necessary control valve and bypass pipeline through the system, so that the function of the independent control of the air-cooled and water-cooled has been achieved, especially in seasons without high According to operation, stop the operation of the newly added circulating water-cooled heat transferor or the primary aircooled (enhanced) and operate the original air-cooled heat transfer alone to save water and electricity resources and reduce production costs, which will, to some extent, increase the flexibility and operability for the maintenance and operation of the oil cooling system. 9

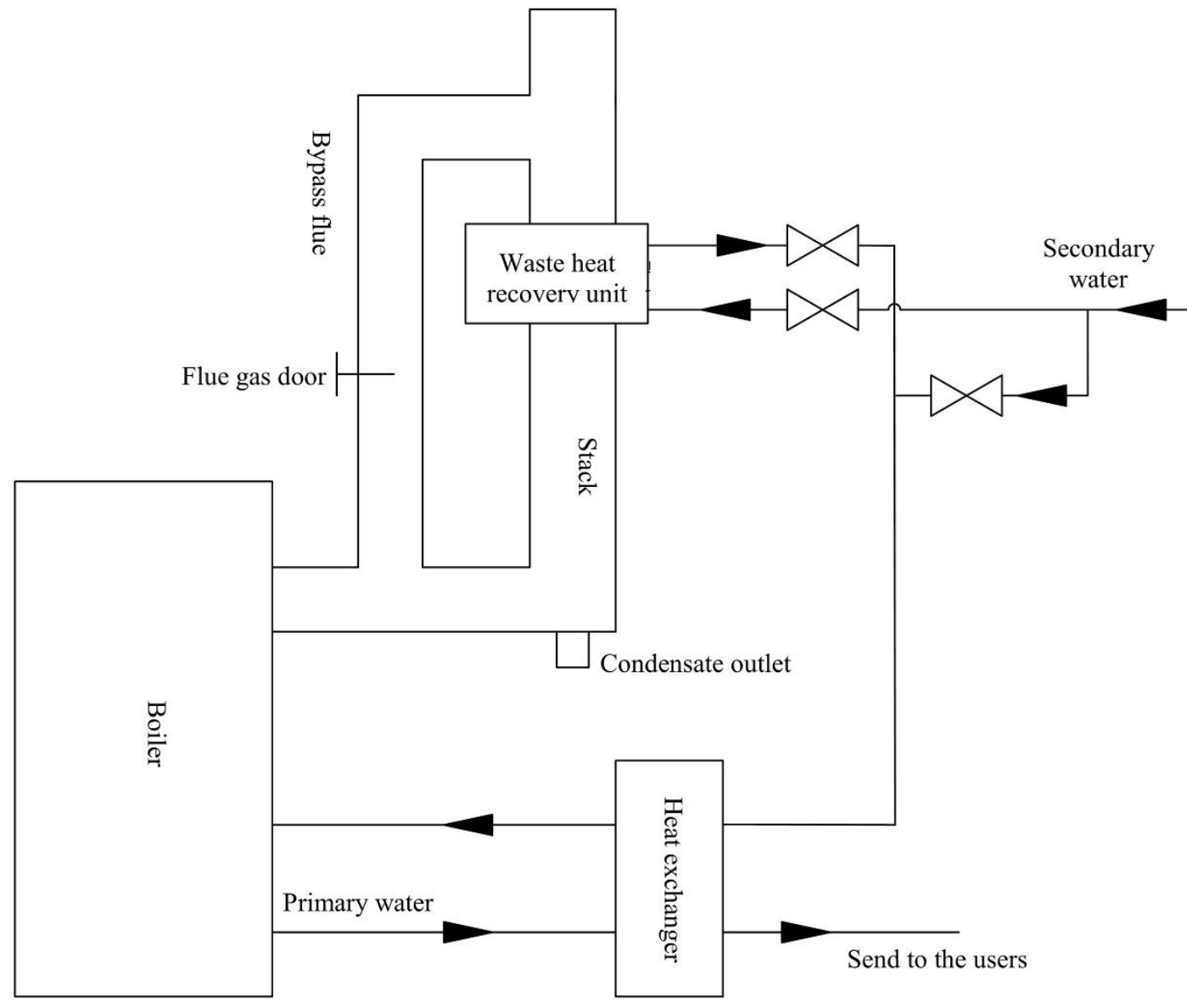

Figure 1: Diagram for the transformation of the oil cooling system of the centrifugal blower 
The average daily operation oil temperature trend of $8 \#$ blower in July before and after the transformation of the oil cooling system of Shidongkou Sewage Treatment Factory is shown in Figure 2. It can be seen from the
Figure that before the implementation of the renovation project of the oil cooling system, changes in the average daily oil temperature curve are relatively big with serious sudden change; after the implementation of the renovation project in 2008, daily average oil temperature curve tends to be straight with relatively small fluctuation range and approaches the optimum operating condition of lubricating oil of about $40^{\circ} \mathrm{C}$.

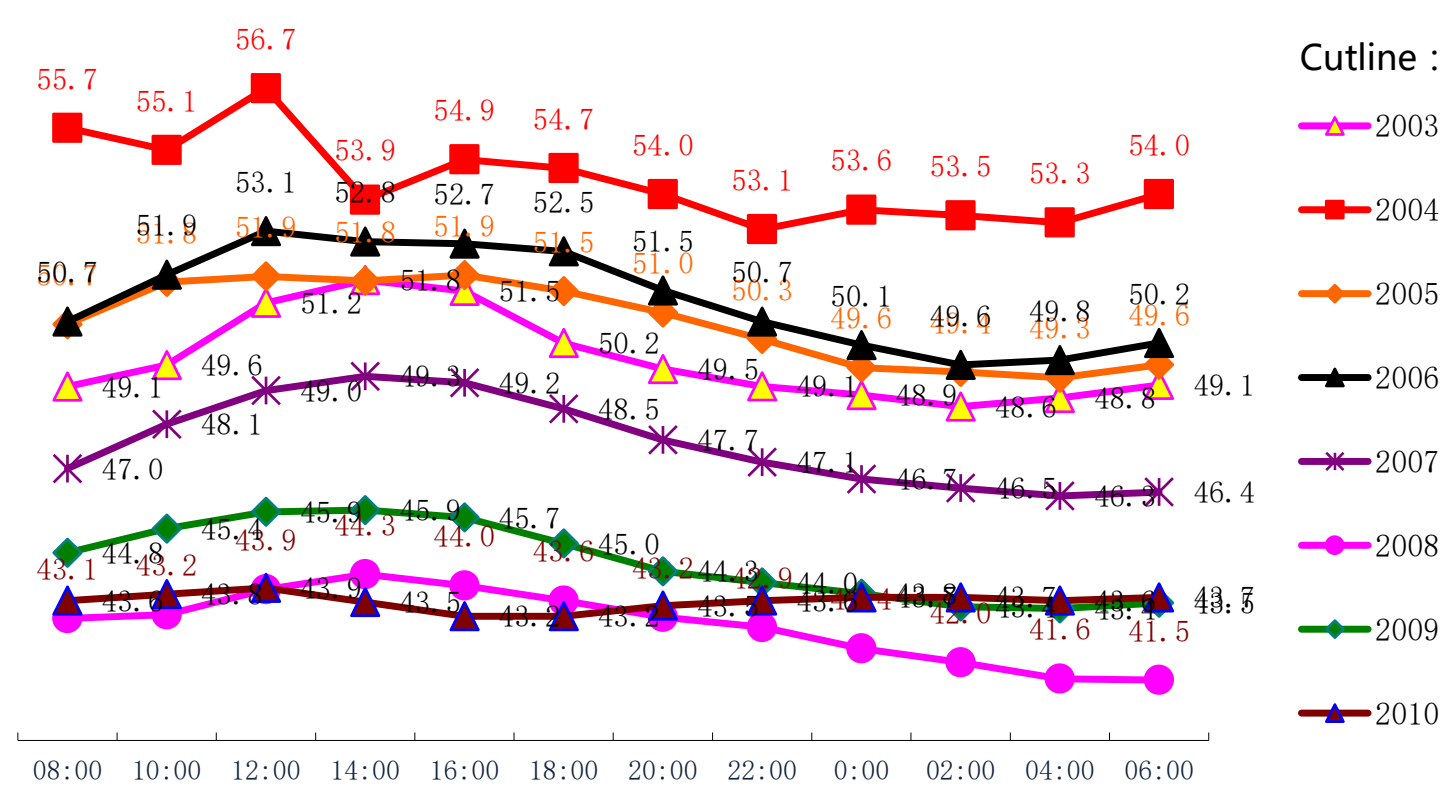

Figure 2: Average daily operation oil temperature trend of $8 \#$ blower in July $\left({ }^{\circ} \mathrm{C}\right)$

The stand-alone operation of the transformed centrifugal blower is stable, and external conditions for normal switching and operation of the blower unit is realized indeed from July 2008 to date, creating more favorable and foundational conditions for the maintenance of the blower unit and management of the equipment. Practice shows that renovation of the oil cooling system basically solves the problem of frequent "high oil temperature" failures of the centrifugal blower that has been troubling Shidongkou Sewage Treatment Factory for many years, which has effectively reduced or eliminated the downtime of the equipment and improved the rate of utilization of the stand-alone equipment.10 Simultaneously, it has better improved the characteristic of lubrication of the centrifugal blower, reduced the energy consumption for the equipment to operate and maintenance costs and extended the service life of the equipment as well as effectively ensured safe and stable operation with standardized production of the Sewage Treatment Factory.

The renovation project adopts measures suiting local conditions, which is suitable for the production and operation of the whole unit, especially for the implementation and promotion of the equipment for the established devices and conditions of the similar scene, which is simple in design, small in investment, small in space, short in construction period and easy in implementation.

\section{Conclusion}

The paper mainly carries out the technical analysis on the causes of high oil temperature failure prevalent in HV-TURBO single- stage high-speed centrifugal blowers to put forward practical and feasible measures and methods, and conducts beneficial attempts of Shidongkou Factory. Good results are obtained in production practice, which further clarifies the necessity of the analysis of reasons of failures and measures, being great reference significance for the proper solution to problems of the same type of equipment under established circumstances.

As the centrifugal blower is operating as a continuous dynamic process, in addition to the improvement of the relevant factors affecting the thermal equilibrium of the oil cooling system and deficiency transformation, it is necessary to strengthen the monitoring and management of the operation. Therefore, the daily cleaning and 
maintenance of the facilities /equipment with the oil cooling system shall be enhanced, and the reasonable maintenance cycle and maintenance solution shall be developed. Take the present Shidongkou as an example for description: (1) Equipment maintenance and cleaning once a week; (2) On-line cleaning of the dust on the surface of the aircooled oil cooler once a month (once a week in summer with high temperature); (3) Change or add the circulating water once a month; (4) Off-line cleaning of the dust on the surface of the air-cooled oil cooler once a quarter, which shall be comprehensively arranged once especially before the arrival of the high temperature season; (5) Offline cleaning and check of watercooled heat exchanger once a year; (6) Cleaning, inspection and maintenance of cooling towers, circulating water pumps, circulating water tanks, pipelines and valves once a year; (7) Adding of the cleaning agent, slow released scale inhibitor and algicide in the system of circulating water once a year; (8) Analysis on the lubricating oil once a year, lubricating the oil once every 3 years $(18,000 \mathrm{~h})$, etc. To further ensure safe and stable operation of the oil cooling system, the aided design of instruments are designed additionally with field level gauge, pressure gauge, thermometer, conductivity meter, online residua Ichlorine comparator and other primary or secondary monitoring instruments to achieve low level alarm, high level alarm and indicators for the halt and operation of the low level lock circulating pump, alarm buzzer and other protection functions.

\section{References}

[1] Jianjun Xiao, Xisheng Wang. Design of the Project of Renovating the Oil Cooling System with Highpressure Centrifugal Blowers [J]. Architectural Engineering Technology and Design, 2017,4. (in Chinese)

[2] Jing Bian, Xiaokang Wang, Hanchao Lu, Ye Shengfu. Analysis on the Application of Blowers in the Industry of Sewage Treatment of Municipal Administrations [J]. China Water \& Wastewater, 2015,31(24):19-24. (in Chinese)

[3] Wenqiang Chen, Baohua Xu. Discussion on the Design, Manufacturing and Installation of Ventilation Ducts [J]. Compressor Blower \& Fan Technology, 2010,3:39-42. (in Chinese)

[4] Zijie Guan. Technology for Diagnosing the Failure in the Lubricating Oil and Equipment [M]. China Petrochemical Press, 2002. (in Chinese)
[5] Kuichang Xu. Blower Manual [M]. China Machine Press, 1999. (in Chinese)

[6] Xiuping $\mathrm{Xu}$. Probe the Installation Technology of Single Grade High-Speed Centrifugal Blower [J]. Wireless Interconnect Technology, 2012, (06):132-133. (in Chinese)

[7] Haitao Xu. Single Grade HighSpeed Centrigugal Blower Installation [J]. Technological Development of Enterprise, 2011,30(05):57-58+97. (in Chinese)

[8] Haijun Xie, Heyi Zhang, Xinhua Zheng. Lubricating Oil Cooling and Filtering Integrated Device for Single Grade High-Speed Centrifugal Blower, CN103644146A[P]. 2014. (in Chinese)

[9] Wenning Cai. Control of Single Grade High-Speed Centrifugal Blower in Sewage Treatment Plant and Realization of Upper Computer Monitoring [J]. China Machine, 2015(24):210-211. (in Chinese)

[10] Hongxing Zhao. Application of Single Grade High-Speed Centrifugal Blower in Sewage Treatment Process [C]. National Sewage Treatment Technology Seminar. 2009. (in Chinese) 